\title{
Return to Slumville: A Critique of the Ackerman Analysis of Housing Code Enforcement and the Poor*
}

\author{
Neil K. Komesart
}

Legal scholarship has shown increasing sensitivity to the income redistributive effects of legal and administrative programs, especially the effects on the lowest income groups. Predictably, this trend has been accompanied by more extensive use of the tools of economic analysis. Many of the programs subjected to this legal-economic analysis distribute their benefits in non-cash forms (e.g., health services, - job training, housing, legal services), generally referred to as "in-kind" transfers. Where the goal of the particular program is the welfare of the low-income recipients, welfare economics traditionally favors programs which distribute benefits in the form of cash transfers, for the recipient can replicate for himself any desired in-kind benefit with the cash transferred. ${ }^{1}$ Thus, a household receiving $\$ 100$ in cash can purchase $\$ 100$ worth of health services, or spend less on health services and allocate the rest to housing, food or recreation. By forcing the recipient household to take $\$ 100$ of health services, the donor government at best gives the recipient the welfare benefit of a $\$ 100$ cash payment, and more probably gives him something less.

Despite this simple but powerful advantage of cash transfer plans, in-kind programs flourish. It is generally thought that in-kind plans are chosen over cash-payment plans not to benefit the direct recipients

\footnotetext{
* Many of my colleagues at the Law School and the Institute for Research on Poverty provided useful comments and criticisms on carly drafts of this piece. In particular, would like to thank my law school colleagues, Professors Cohen, Heller, Schneyer and Finman as well as the members of the Poverty Institute's workshop on income distribution and its leader, Gene Smolensky. Any success of this piece must be partly theirs; its crrors belong only to me.

$\dagger$ Assistant Professor of Law and Associate of the Institute for Research on Poverty, University of Wisconsin. A.B. 1963, A.M. 1964, J.D. 1967, Ph.D. Economics 1973, University of Chicago.

1. This presumption is subject to important caveats. The "paternalistic" approach suggests the possibility that the low-income recipients determine this utility in a faulty manner. To the extent that "paternalistic" legislation provides needed information, it can be viewed as providing two in-kind transfers (c.g., health and knowledge). To the extent that "paternalistic" legislation provides benefits for individuals other than the direct recipients, it is covered by the following textual discussion.

The market may also be unable or unwilling to provide the service to the low-income purchaser. Racial discrimination is the most of -cited obstacle facing the low-income cash recipient in his efforts to replicate the in-kind service through market purchase.
} 
but to please the donors. Thus, some members of society may gain greater donative utility if their tax funds reach low-income recipients in specified forms rather than in the less restrictive form of cash. Others may gain benefits from the aesthetic improvements inherent in better neighborhood housing or better clothed neighbors. However, these indirect recipients are unlikely to be of low income. Where the object of government expenditure is the increased welfare of the poor, in-kind programs would still appear presumptively inferior to cash payment programs.

Given this analysis, it is an important event when an addition to the legal literature announces the discovery of a conceptual framework which establishes the a priori superiority on redistributive grounds of an in-kind program over cash payments. The in-kind program considered involves the increased quality of rental housing for low-income families. In support of the program involved, the study dismisses many problems which have heretofore haunted analysts of the rental housing market. The complex and critical nature of the housing market combined with these bold assertions add to the importance of the claims made in this study. I refer to Professor Bruce Ackerman's 100. page discussion of housing code enforcement and income redistribution which appeared in this journal. ${ }^{2}$ While Professor Ackerman deserves commendation for his courage in assaulting established doctrine, his analysis is basically flawed and his conclusions suspect. If the problems in issue were less important or if the solutions to these problems could be determined intuitively, this critique would be unnecessary. However, the problems of low-income housing are both important and highly complex. In addition, the mode of analysis chosen by Professor Ackerman requires special critical appraisal. Economic analysis can make significant contributions to the legal literature. However, the complexity of the analysis and its unfamiliarity to many of the readers of legal journals require additional care on the part of the analyst. If the tools of economics are to realize their potential in the context of legal scholarship, they must be carefully employed. The importance of the problems, as well as the novelty and potential value of the analytical tools, justify further discussion of Professor Ackerman's article. ${ }^{3}$

2. Ackerman, Regulating Slum Housing Markets on Behalf of the Poor: Of Housing Codes, Housing Subsidies and Income Redistribution Policy, 80 YAt. L.J. 1098 (1971) [hereinafter cited as Regulating Slum Housing].

3. The importance of correcting any misconceptions created by Professor Ackerman's article is far from speculative. Its portrayal of the forces at work in the urban housing mar. ket has apparently influenced the outcome of at least one recent landlord-tenant decision 
Professor Ackerman's basic presentation may be outlined as follows:

(1) If the supply of slum housing units is fixed and unresponsive to increased costs of production, and the demand is responsive to changes in rent, the increased costs imposed on landlords by code enforcement will not be passed on to tenants as increased rent

(2) If the supply is not fixed, then a code enforcement plan plus a government housing subsidy will produce a situation in which the tenant again will receive higher quality housing without any increase in rent.

(3) If the costs to landlords are ignored in the determination of social value, a "leverage" effect exists such that a code enforcement plan which distributes its benefits in the form of rental-unit quality improvements has a presumptive advantage over cash-payment plans on redistributive grounds.

(4) The additional costs imposed on landlords by the code enforcement will have virtually no effect on investment in either low-income housing or housing in general and therefore no appreciable decrease in the supply of low-income rental units will occur.

(5) Improved housing will not prompt any appreciable in-migration of tenants into the area. Therefore, there need be no concern about possible increased rents from this source.t

The first part of this critique will assume the validity of Professor Ackerman's models and his postulates in order to focus on an examination of the "leverage" effect. The second part will examine these models and the assertions which seemingly allow Professor Ackerman to transform his models into reality.

of great potential import. Thus, in Robinson v. Diamond Housing Corp., 463 F.2d 853 (D.C. Cir. 1972), Judge J. Skelly Wright reasoned as follows:

Of course, if the housing market is structured in such a way that it is impossible for landlords to absorb the cost of bringing their units into compliance with the housing code, there may be nothing a court can do to prevent vigorous code enforcement from driving low-cost housing off the market. But the most recent scholarship on the subject indicates this danger is largely imagined. In fact, it appears that vigorous code enforcement plays little or no role in the decrease in low-cost housing stock. Then code enforcement is seriously pursued, market forces generally preveni landlords from passing on their increased costs through rent increases. See generally Ackerman, Regulating Slum Housing Markets on Behalf of the Poor: Of Housing Codes, Housing Subsidies and Income Redistribution Policy, 80 Yale L.J. 1093 (1971). 463 F.2d at 860 (footnote omitted).

Such a conception of the housing market may be substantially crroncous and the cf. fects of decisions based upon this conception may differ materially from those expected. It is important that the legal community be aware that not all "recent scholarship" can portray so manageable a housing market.

4. This outline is not meant to cover every point made by Professor Ackcrman. It is meant to portray the basic core of Professor Ackerman's discussion and the basic areas in which criticism is necessary. The arguments used to support these points will be the subject of the rest of the article. 


\section{The "Leverage" Effect}

Professor Ackerman sets out his initial models by using a hypothetical substandard housing area, Slumville, in the center of a hypothetical city, Athens. He argues that with a given level of government subsidy the imposition of a blanket code enforcement program would raise the quality of the housing without leading to any increase in rent. ${ }^{5}$ Having propounded his program, Professor Ackerman contrasts it with an income maintenance or cash-payment alternative. He concedes that the utility to the household of a dollar in cash would be at least as great and probably greater than a dollar's worth of increased housing quality, ${ }^{6}$ but he argues that there exists an "extra dimension" which gives in-kind programs an advantage over cashpayment programs. He contends that this added dimension requires only the initial assumption that any costs to landlords associated with improving the quality of housing will not be computed as social costs in his system. This assumption itself should be subjected to closer scrutiny. ${ }^{7}$ However, since the "leverage" effect which is the ob. ject of this assumption is invalid even given the assumption, it is not necessary to debate the assumption here.

Assuming then that only "governmental costs" will be counted, Professor Ackerman displays his "leverage" effect with an arithmetic example which employs the following figures:

(1) The costs imposed on landlords by increased code enforcement will cause them to remove 3,000 of the 100,000 units from the Slumville rental housing market unless government subsidy is provided.

(2) The government subsidy necessary to keep these 3,000 units on the market is $\$ 50$ per unit per month. ${ }^{8}$

(3) The average terant family values the increment in quality caused by code enforcement at $\$ 20$ per unit per month.

5. Professor Ackerman's models and their assumptions will be examincd subscquently. For the purpose of the present discussion, his models will be assumed correct.

6. The rationale for this argument was discussed in the introduction to this articlc.

7. The assumption places no societal value on a dollar taken from the landlord so long as it is given to the tenant. This scheme should be distinguished from one in which less societal value is given to the landlord's utility. Professor Ackerman's scheme implicitly values the utility of the tenant as infinitely greater than that of the landlord, not just twice or ten or one hundred times greater. Considering Professor Ackerman's own realization that many slum landlords are low-income slum dwellers, such a scheme of societal value seems harsh.

8. Professor Ackerman never indicates the form of this subsidy. If the money is to go to those landlords who are about to exit the market, all landlords will have an incentive to claim that they would leave. This problem could be solved by the building of public housing, but there would still be problems in determining the number of units necessary until the Slumville housing market had reached some equilibrium position.

However, for the purposes of this article, Professor Ackerman's unarticulated, distortionless, instantaneous subsidy system will be assumed. 
He proposes the following table to display his "extra dimension":"

PROGRAM

Code enforcement-

housing subsidy
cosTs

3,000 families
$\times \$ 50$ per month $=\$ 150,000$

Income

maintenance

3,000 families
$X \$ 50$ per month $=\$ 150,000$

97,000 BENEFITS

97,000 families in un-

subsidized housing $x$

$\$ 20$ per month

3,000 families in

subsidized sector $X$

$\$ 20$ per month

3,000 families

$\times \$ 50$ per month
$=\$ 1,940,000$

$=\$ 60,000$

$\$ 2,000,000$

$=\$ 150,000$

According to Professor Ackerman, the "leverage" effect exhibited in this table provides his in-kind program with a theoretical superiority over cash-payment programs so strong that it now forces proponents of cash-payment plans to turn to ad hoc empirical arguments most of which Professor Ackerman discusses and dispatches.

Professor Ackerman describes the explanation of this remarkable discovery as "quite simple" and imparts it in a few sentences:

An expenditure of government funds on a negative income tax does not permit the government to initiate a second program which redistributes additional income to the poor at no expenditure of government money. A dollar spent on a negative tax yields a dollar in benefits to the poor: there is no "leverage" effect. In contrast, a dollar spent on a special purpose housing subsidy does have a "leverage" effect since it permits the government to initiate a second income redistribution program-comprehensive code enforcement-at no increase in government expenditure. Thus a dollar spent on the special housing subsidy not only benefits the direct recipient of the subsidy but also benefits all those families who receive better private rental housing-at no increase in rent-as a result of code enforcement. ${ }^{10}$

Professor Ackerman appears to assume that a program which distributes its benefits in the form of cash payments cannot tap the "costless" fund provided by the landlord's contribution. If cash-payment plans can be funded from Professor Ackerman's "costless" landlord fund, then such cash-payment plans are not inherently inferior to inkind housing programs because of any "leverage" effect. The "leverage" effect established at the cost of such severe assumptions would be meaningless and the state of knowledge would return to its preAckerman level.

9. The table is presented in Regulating Slum Housing, supra note 2, at 1121. The "leverage" effect discussion occurs id. at 1119.29.

10. Id. at 1122 . 
Cash-payment plans of many varieties can be fashioned to tap Professor Ackerman's "costless" fund. Every violating landlord or every landlord in Slumville $\mathrm{e}^{11}$ could be taxed in the amount of the improvement costs and the receipts placed into a special fund. The "landlord fund" could be distributed to the tenants of these landlords or to tenants in general or to the poor in general. Perhaps the "cash payment" program most parallel in logistics to Professor Ackerman's own plan would be the imposition of rent control in Slumville ${ }^{12}$ with rents reduced by the amount the landlord otherwise would have had to pay for quality improvement. ${ }^{13}$

Whatever the plan chosen, once the assumption is made that costs to landlords are not counted as costs to society, any program funded by these landlords' costs has the "leverage" effect regardless of the form in which it distributes its benefits. The "leverage" effect exists on the cost and not on the benefit side.

The trivial nature of the "leverage" effect becomes obvious when Professor Ackerman's accounting system and his "mathematical" example are more carefully examined. To expedite this process, an additional table has been compiled which reflects not only Professor Ackerman's programs and accounting system but an additional program and a more complete accounting system:

\begin{tabular}{|c|c|c|c|}
\hline PROGRAM & $\operatorname{cosTS}(A)$ & BENEFITS & $\operatorname{cosTs}(\mathrm{C})$ \\
\hline $\begin{array}{l}\text { Ackerman's Housing } \\
\text { Program }\end{array}$ & $\begin{array}{l}3,000 \times \$ 50= \\
\$ 150,000\end{array}$ & $\begin{array}{l}97,000 \times \$ 20= \\
\$ 1,940,000 \\
3,000 \times \$ 20= \\
\$ \quad 60,000 \\
\$ 2,000,000\end{array}$ & $\begin{array}{l}\$ 4,850,000+ \\
\$ 150,000= \\
\$ 5,000,000\end{array}$ \\
\hline $\begin{array}{l}\text { Ackerman's Income } \\
\text { Maintenance Program }\end{array}$ & $\begin{array}{l}3,000 \times \$ 50= \\
\$ 150,000\end{array}$ & $\begin{array}{l}3,000 \times \$ 50= \\
\$ 150,000\end{array}$ & $\begin{array}{l}3,000 \times \$ 50= \\
\$ 150,000\end{array}$ \\
\hline $\begin{array}{l}\text { Income Maintenance Pro- } \\
\text { gram with same fund- } \\
\text { jng as Ackerman's } \\
\text { Housing Program }\end{array}$ & $\begin{array}{l}3,000 \times \$ 50= \\
\$ 150,000\end{array}$ & $\begin{array}{l}97,000 \times \$ 50= \\
\$ 4,850,000 \\
3,000 \times \$ 50= \\
\$ 150,000 \\
\$ 55,000,000\end{array}$ & $\begin{array}{l}\$ 4,850,000 \text { (from } \\
\text { landlords' fund) }+ \\
\$ 150,000 \text { (from } \\
\text { gencral funds) }= \\
\$ 5,000,000\end{array}$ \\
\hline
\end{tabular}

11. The model which provided the context for Professor Ackcrman's "leverage" proof assumed that all the housing in this particular area was uniformly substandard. Given this assumption, all the landlords in the designated area could be taxed without the administrative costs of code inspection.

12. Rent control may be associated for many readers with ineffective enforcement in a tight housing market, diminution in incentive to build new housing, removal of housing from the market, or decreased quality of rental units. These are potential problems in the real world, not Professor Ackerman's world. The assumption of unresponsive (fixcd) supply and responsive demand plus the monumental assumptions of no in-migration and no effect on housing investment will as easily support an effective rent control pro. gram as it will a code enforcement program.

13. The $\$ 150,000$ "government subsidy expenditure" can also assume varied roles in the context of the various cash-payment plans. It can be paid as rent subsidies to landlords in order to maintain the number of housing units at 100,000 , its role in Professor Ackerman's in-kind program, or it could be paid as additional direct cash payments to those tenants who were evicted from the 3,000 units. 
The upper right hand quadrant of Table II is the same as Professor Ackerman's table. The figures listed under "costs (A)" reflect Professor Ackerman's "costless" fund accounting system. Those listed under "costs (C)" represent the cost figures including the resource cash of quality improvement expended by the landlords.

When all costs are counted (costs (C)), Professor Ackerman's preferred program appears substantially inferior to either his income maintenance program or an income maintenance program which is funded in a manner comparable to his preferred program.14 His program shows a negative net benefit (deficit) of $\$ 3,000,000$ while the other programs show no deficit: his program is $\$ 3,000,000$ inferior to the others. The deficit reflects the fact that the recipients of $\$ 50$ worth of housing quality value it at less than $\$ 50(e . g ., \$ 20)$ while recipients of $\$ 50$ in cash value it as $\$ 50$.

Employment of the "governmental expenditure" accounting system espoused by Professor Ackerman (costs (A)) manages to turn "deficit" to "benefit" with Professor Ackerman's preferred program now exhibiting positive net benefits of $\$ 1,850,000(\$ 2,000,000-\$ 150,000)$. The benefits associated with Professor Ackerman's income maintenance plan remain unaltered with the switch in accounting system because that plan was not privileged to tap the "costless" fund, the landlords who lay the golden egg. However, an income maintenance program with funding comparable to Professor Ackerman's preferred program shows net benefits of $\$ 4,850,000(\$ 5,000,000$ - $\$ 150,000), \$ 3,000,000$ more than Professor Ackerman's program. The advantage of the comparable income maintenance program over Professor Ackerman's pro-

14. The landlord's cost figure of $\$ 4,850,000$ per month was arrived at by multiplying 97,000 rent units times $\$ 50$ per unit per month. The number of rental units comes directly from Professor Ackerman's assumption about the number of units which would remain on the market and bear the costs of quality improvement without subsidy. The $\$ 50$ figure comes from Professor Ackerman's assumption that a subsidy of $\$ 50$ per unit per month would be necessary to keep the 3,000 rental units available to the tenants. If anything, the $\$ 50$ is probably an underestimate of the implicit cost figure inherent in Professor Ackerman's hypothetical. The subsidy would equal the cost only if the 3,000 units had had no excess return relative to other uses (if revenue just covered variable costs). Under those circumstances all the costs would have to be subsidized in order to keep the units on the rental market. To the extent that some "excess revenues" are present, there are costs which will not have to subsidize but can instead be imposed on these landlords in the same manner in which the total costs were imposed on the 97,000 other units. Thus, in these cases, the observed subsidy is less than the unobserved cost involved.

This process can be seen algebraically as follows: $C=q+S$, where $C$ represents costs, $q$ represents quasi-rents and $S$ represents the subsidy. For the 97,000 rental units $q>C$ (quasi-rents are greater than costs) and no subsidy is necessary. For the 3,000 units, $q<\mathrm{C}$ (quasi-rents will not cover all costs). To the extent that quasi-rents are present at all $(q>0)$, subsidy will be less than cost $(S<C)$ since $S=C-q$.

The reader need not greatly concern himself with this discussion since any cost figure arbitrarily substituted for the $\$ 50$ figure will still show Professor Ackerman's "Icicrage" effect to be meaningless. 
gram remains the same no matter which accounting system is employed. Professor Ackerman's "leverage" effect was produced by comparing non-parallel examples of in-kind and cash-payment programs. When the parallel situations are compared, either accounting system negates the existence of any "leverage" effect.

While Professor Ackerman fails to deal with comparably financed cash-payment programs in the context of his "leverage" effect discussion, he belatedly recognizes their existence more than fifty pages after he has apparently closed his "leverage" discussion. This delay combined with his failure to connect this subsequent discussion with the "leverage" effect gives a misleading impression of the theoretical strength of his "leverage" effect even were his attempt to dismiss the alternative cash-payment plans successful. However, his belated arguments concerning these alternatives are unsound and fail to rejuvenate the "leverage" effect.

Professor Ackerman discusses two types of cash-payment plans capable of tapping the landlord fund. ${ }^{15}$ The first he labels the "slumlord tax" plan: the costs of quality improvement are collected, placed in a fund and paid to the tenant of the offending landlord. Professor Ackerman contends that this plan is defective in two senses. If the amount collected were equal to the amount the landlord would have had to spend for quality improvement, the landlord would presumably choose to make the quality improvement or at least he would be indifferent. ${ }^{16}$ This assertion is correct but hardly provides any "leverage" or other advantage for his code enforcement program. The cash-payment program would simply approximate the code enforcement program to the extent that the landlord substituted quality im. provements for tax payments. However, a tax set slightly lower than the improvement costs would avoid even this result: $A$ tax of $\$ 45$ rather than $\$ 50$ would make everyone better off. The landlords would avoid the improvement and pay $\$ 5$ per unit per month less. The tenants would receive cash benefits they valued at $\$ 25$ per month

15. In theory, even were he successful in negating the two variants he discusses, Pro. fessor Ackerman's attempt to support his "leverage" effect would fail since it must be shown that all cash-payment forms are incapable of tapping the landlords' fund. How. ever, since his argument as to the two variants is faulty, this approach necd not be cmphasized. These two arguments occur in Regulating Slum Housing, supra notc 2, at $1182-86$.

16. It might seem that as between paying the cash in the form of a fine or improving the quality of his rental units, the landlord would choose the latter since he would recoup at least a part of the loss in the form of higher property value. However, Pro. fessor Ackerman has engineered his system so that no rent increase is associated with any quality-improvement expenditure. Without rent increase, the value of the rental units should not rise and the landlord would be indifferent among the tax, the im. provements and in fact simply destroying the money. 
more than the quality improvements.

Professor Ackerman approaches this problem by asserting that in response to a lesser tax of $\$ 20$ per month (why $\$ 20$ instead of $\$ 45$ ), the landlord would simply raise his rent by $\$ 20$ and recover the full amount from his tenant. At first blush, such a process seems consistent with intuition. But is it consistent with Professor Ackerman's model? How can a landlord who could not pass on the cost of improving his rental units to his tenants, now pass on the cost of the slumlord tax to his tenants? Professor Ackerman's model would seem to foreclose any recapture of the slumlord tax through rent increase. Yet in his slumlord tax discussion Professor Ackerman asserts that the landlord will automatically recapture his costs through rent increase. Peculiarly enough, neither answer is correct. Due to the economic assumptions made by Professor Ackerman, it is indeterminate whether the slumlord tax can be passed on in the form of higher rent.

Professor Ackerman's assumptions fix the number of rental units, make the supply side unresponsive to cost changes, and seemingly negate rent increase. ${ }^{17}$ However, the demand side is also unresponsive. The cash payment and the increased rent take the same form. While it is possible to conceive of "lukewarm" tenants who value quality improvements costing $\$ 50$ at a cash equivalent less than $\$ 50, \$ 50$ in cash will by definition be valued at a cash equivalent of $\$ 50$. Both supply and demand are unresponsive. Economic theory will not yield a solution. ${ }^{18}$ Thus, even given his assumptions, Professor Ackerman cannot correctly assert that the slumlord tax will be passed on.

However, several alternative changes can be made in the cash-payment plan which will avoid even this indeterminacy and foreclose any recapture of the slumlord tax through rent increase. The most obvious such change would be the inclusion of a provision fixing rents at their pre-tax level. Such a program would allow the benefits to be distributed in cash (e.g., \$45) and assure the tenant of no rent increase. ${ }^{19}$

17. These assumptions are presented and discussed in notes 25.28 infra and accompanying text.

18. While the market does not yield a determinate solution, the relative bargaining skills and power of the parties might. However, there is no a priori basis for determining the direction of that solution.

Thus, the landlord may have superior bargaining skills and on that ground pass the rent on. On the other hand, the existence of $a$ coalition of tenants which would threaten the evacuation of rental units would force the trend in the other direction. It should be recalled that Professor Ackerman assumes no in-migration of tenants. If any of Slumville's population decides to double-up, if any out-migration occurs, or the population is diminished by death this would provide sufficient sensitivity on the demand side to negate the attempt to pass on the costs of the slumlord tax.

19. As suggested previously, a general rent control scheme which lowers Slumville rents by $\$ 50$ or less would provide a cash-payment plan with logistics analogous to Professor Ackerman's preferred program. There would be no need for the government ap. 
An alteration in the definition of the recipient unit could also avoid the indeterminacy and assure that rents would not increase. The $\$ 45$ per month could be paid to each Slumville family whether or not it continued to occupy a single rental unit. Since the cash payment would no longer be contingent on occupancy of a separate divelling unit, families could double-up rather than face rent increase. ${ }^{20}$ Landlords would confront the same vacancies which forced them to absorb the costs of quality improvement under Professor Ackerman's model. ${ }^{21}$

The slumlord tax plan is Professor Ackerman's invention. Even against this plan of his own construction, his arguments are ineffective. Feasible variations in this program disarm his arguments completely. ${ }^{22}$

Professor Ackerman also assails the would-be proponents of schemes which call for the distribution of the landlords' fund to the poor in general. His argument is in fact no argument at all. ${ }^{23}$ Professor

paratus to either collect or disburse any funds. The cash payment would take the form of a rent reduction by the landlord to his own tenant. The process is analogous to that employed in the "implied warranty of habitability" cases such as Javins v. First National Realty Corporation, 428 F.2d 1071 (D.C. Cir. 1970), where rent was theoretically reduced to the extent of diminution in habitability.

The effects of rent control or other rent reduction programs in the real world are problematic. But no concern need be given these problems in the context of Professor Ackerman's world. See note 12 supra.

20. All the mechanisms available to the tenant population in avoiding rent increase in Professor Ackerman's plan are available here: doubling-up, living on the street, political activity, etc. As long as payment is not conditioned on occupancy of a single rental dwelling unit, it is no different in effect than a neutral increase in the tenant's income. The landlord in Professor Ackerman's model is in no position to appropriace this increase.

21. There are again problems with such a scheme in the real world since there would be an incentive for in-migration and the vacancies might be filled. However, Slumville is Professor Ackerman's world and he assumes no in-migration. Such an assumption is necessary for his plan to succeed, but by making the assumption he pro. duces success for plans which are alternatively superior to his preferred plan.

22. Professor Ackerman offers another argument against the slumlord tax which deserves brief mention here. He insists that such a plan would necessitate an "adminis. trative behemoth" which must not only inspect for code violations but also collect these funds from unwilling landlords. It is difficult to see why such a structure would be more costly or cumbersome than the structure implicit in his code enforcement plan. The landlords who are ordered to make quality improvements are not likely to comply instantaneously. It would appear easier to collect $\$ 45$ from an uncooperative landlord than to force $\$ 50$ worth of quality improvements. The latter involves re-inspection, and evaluation of quality. Such evaluations may provide the landlord with an excuse for cx. tensive litigation in an effort to delay the enforcement process. It is difficult to conccive of a "behemoth" of more terrifying dimensions than that involved in Professor Ackerman's code enforcement plan. Also, such administrative problems can be minimized by adoption of a rent control or general tax scheme.

23. Professor Ackerman's "argument" is as follows:

When faced with these insurmountable obstacies, the "tax-grant" advocate most probably will be tempted to alter his proposal one final time, and suggest that in. stead of compensating Slumville's tenantry, the revenue raised from the slumlord levy should be placed in the general fund for worthy governmental purposes among which redistribution may be numbered. By revising the proposal in this way, however, the "tax" proponent has removed the only feature distinguishing it from the code enforcement alternative. For absent any effort to compensate the tenantry in cash, a "slumlord tax" is but a different label for a housing code enforced by "fines": if the "taxes" are very high, slum landlords will improve (or abandon) all their buildings to free themselves of their potential tax liability, just as they would when threatencd 
Ackerman simply asserts that the effects of such a plan would be de minimis. If he is concerned that the number of recipients will be too large, and therefore the amount received by each too small, the number of recipients could simply be reduced. Funds could be distributed to all those living in Slumville or to all the poor in Athens below an income level determined so as to select the number of recipients desired. The figures in Professor Ackerman's own arithmetic example indicate that a cash-payment plan has $\$ 3,000,000$ more in benefits to distribute than his in-kind plan. Surely the recipient base can be expanded by a sizeable amount without providing lower benefits per recipient than Professor Ackerman's preferred plan.4t

It has not been the object of the preceding discussion to promote a slumlord tax plan, or a plan which distributes the landlords' fund to the poor in general, or a rent control plan. These plans have been suggested in the context of Professor Ackerman's models, his accounting system, and his theoretical "leverage" concept. In that context, these cash-payment plans are superior to his preferred plan. What has been

by heavy "ffines"; if the tax is lower, the result will be identical to partial code enforcement; if so low as to be de minimis, the result will be equivalent to ineffective enforcement:

Regulating Slum Housing, supra note 2, at 1185.

The "insurmountable obstacles" refer to Professor Ackerman's arguments about the slumlord tax plan and have already been "surmounted."

24. Perhaps Professor Ackerman is attempting to introduce some "political reality" and suggesting that if the landlords' fund were collected, it would not go to the poor. This point might have validity in the real world. But if the realities of the world are introduced, we must examine possible subversion of a code cnforcenent plan by those with resources to hire attorneys, bribe inspectors, or place political pressure on the code enforcement authority. Since Professor Ackerman cannot make his system work in his own abstract model, he can have little room for ad hoc "political reality" anguments.

Professor Ackerman offers two other arguments for code enforcement over eash-payment plans: (1) enforcement creates public goods and external bencfits and (2) housing improvement exhibits scale economies enjoyable by landlords only when all or almost all of the units under their control are being renovated or improved. Regulating Slum Housing, supra note 2, at 1177-79, 1181 .

Both considerations are standard in the evaluation of any program. One can also marshal a series of ad hoc "externality" and "cconomy of scalc" arguments in favor of cashpayment plans (e.g., reduced crime rates, increased quality of political participation, cconomies of scale for purchase by low-income consumer cooperatives). It does not take much imagination to produce such arguments in the abstract. However, without some indiention of the extent of these effects, an argument which merely notes their cxistence is ineffectual. The effects might be substantial or they might be de minimus. Professor Ackerman attempts no estimation of the size of these effects or of effects associatcd with competing plans.

In addition, even if there were substantial public good and seale cffects, it is not clear who would receive the benefits. In-kind programs may produce substantial benefits for the non-poor. These programs may be justified on the basis of such benefits, but not on the basis of their distributive effects. Since Professor Ackerman's program vould force the Iandlord to achieve a prescribed level of quality, any reductions in cost associated with externalities produced by the similar activities of neighboring landlords would seem to accrue to the landlord, not the tenant. In reality, it is questionable how: much of these benefits would accrue to low-income landlords. In Professor Ackerman's world, none of such benefits would be reflected unless they happened to reduce the government subsidy. 
shown is not the success of these plans but the illusion of Professor Ackerman's "leverage" concept, and the dubious nature of his model. The lesson is a melancholy one: knowledge about in-kind versus cashpayment plans has not been advanced.

\section{Empirical Assumptions}

Professor Ackerman's first model has nine explicit assumptions ${ }^{3 \mathrm{i}}$ along with an implicit tenth. ${ }^{26}$ One set of assumptions fixes the sup. ply of rental units in Slumville and makes that supply unresponsive to the increase in costs caused by code enforcement. ${ }^{27}$ On the demand side Professor Ackerman produces tenant responsiveness to rent increases by assuming that tenants are knowledgeable and mobile, and that they vary in their taste for quality increments. ${ }^{28}$ Such a model allows increase in quality through code enforcement while foreclosing rent increase. Within the assumptions, Professor Ackerman's conclusions are valid if not startling.

The second model relaxes the assumptions which fix the quantity of rental units supplied. However, the second model unlike the first yields no pertinent conclusions even if its assumptions are accepted as realistic. The second model assumes that the number of low-income rental units supplied will respond to cost changes. However, the fact of response of itself neither supports nor rejects any program or policy. It is the degree of response which is crucial. Aware of this fact, Professor Ackerman presents a series of arguments which attempt to mini-

\footnotetext{
25. The nine explicit assumptions are described by Professor Ackerman as follows: For purposes of the present discussion, then, assume (1) both landlords and tenants act rationally in their self-interest; (2) no landlord or group of landlords has successfully established a monopoly or oligopoly position in the rental markct: (3) tenants are aware of the range of prices and quality levels of accommodations offered for rent in Slumville and experience no significant cost in moving from one part of Slumville to another; (4) all of Slumville's accommodations are not only slums, but are equally slummy; (5) similarly, all of Slumville's tenants inflict equal damagc upon the physical structures of the houses in which they reside; (6) a significant number of poor provincials are not entering Athens from the outlands nor are Slum. villites emigrating to the hinterlands; (7) each and every landlord in Slumville carns a rate of return on his investment which substantially exceeds the return available when the property is used for other purposes; indeed (8) even if the landlords are forced to bring their residential properties up to code, their rate of return would still exceed that available for any other use of the property; and (9) no landlord will find it more profitable to abandon his building entirely when faced with the necessity of investing substantial sums to bring his tenement up to code.

Regulating Slum Housing, supra note 2, at 1102-03 (footnotes omitted).

26. It is also assumed that not all tenants have the same taste for increments in housing quality, and that at least a small group places virtually no value on the marginal quality increment envisioned by the new code enforcement program.

27. Assumptions (7), (8), and (9) are directly applicable. See note 25 supra.

28. See assumption (3) in note 25 supra and the implicit assumption observed in note 26 supra.
} 
mize the extent of response by suppliers of rental units to the imposition of the additional costs of quality improvement. In addition, he argues that the improved quality of housing will not increase appreciably the demand for these units via in-migration to the slum area.

Professor Ackerman's arguments contain critical analytical errors and his assertions present an erroneous impression of the state of knowledge. If accepted as valid, Professor Ackerman's analysis and factual assertions would prompt a misallocation of research interest and resources. On those grounds his arguments are worth examination.

\section{A. The Rate of Rental Unit Removal}

Even if it is assumed that greater code enforcement would cause no present diminution in the Slumville housing supply (the outcome produced in Professor Ackerman's first model), it still becomes necessary to consider what will happen to that supply as time passes. The constant housing supply derived in Professor Ackerman's first model followed from his assumption that landlords would have sufficient revenue to cover variable costs even when the additional code costs were included. Professor Ackerman emphasized that he did not assume that investment in housing received any unusual return; he based his constant supply solely upon the ability of landlords to continue to meet variable cost. Underlying Professor Ackerman's conclusion is an unarticulated standard proposition of economic analysis which holds that a firm will not cease operations so long as its revenue covers variable cost. However, it is also a proposition of economic analysis that fixed costs become variable costs over time. In more common sense terms, the physical structure which houses the rental units depreciates over time. At some point, as time passes, each of the structures will need refurbishing or rebuilding. At this point, the variable costs relevant to the decision to continue in the rental business will include elements of formerly fixed costs and the decision to remove rental units will be contingent upon a sufficient return on investment in housing. Thus, even if the immediate supply of rental units is constant, the supply will not remain constant as time passes, and its rate of change will depend on the costs of continued operation including those associated with code enforcement.. ${ }^{20}$ The removal of 3,000 units which Professor Ackerman hypothetically

29. If the code enforcement costs were imposed only in the first year and not again, this long-term effect could be ignored. However, as Professor Ackennan's own continuing subsidy ( $\$ 50$ per month) indicates, the maintenance of a given standard of quality demands continued investment over time. 
visualizes in his "leverage" effect example may only be the figure at the end of the first period..$^{30} \mathrm{By}$ the second year the number may be 3,500 and the "government" subsidy $\$ 175,000$ per month for that year. In the third year the attrition may reach 4,000 and the subsidy would be $\$ 200,000$, etc. While the figures utilized are hypothetical, the effect is real. Eventually the owner of the parcel will be in a position to choose between rebuilding and fleeing the rental-unit mar. ket. At that point, the existence of additional costs imposed by code enforcement will make flight more attractive. Professor Ackerman ignores this increased diminution in supply over time.

\section{B. Effects on Construction of New Housing}

In one page, Professor Ackerman disposes of two other aspects of the supply question: the adverse effect of increased costs on the rate of low-income housing construction and the adverse effect of increased costs on construction of higher-income housing with its indirect effect on the supply of low-income housing through "trickle down."

His approach is, to say the least, cavalier. As to low-income housing he states:

It may be argued that imposing "code costs" upon Slumville owners will discourage new housing construction in the private sector, thereby lowering the supply of housing to low income groups in the long run-which in turn will mean an increase in rents to the poor. If it were economically feasible for the private sector to build new housing for the poor without government subsidy, this objection would have very substantial weight. But, in fact, unsubsidized new construction for the poor has long since ceased to be economically feasible. ${ }^{31}$

This argument is analytically unsound. Whether the present market conditions require subsidy is irrelevant to an economic analysis of the impact of code enforcement on low-income housing construction. Code enforcement involves additional costs for the housing investor both initially and in maintenance. These additional costs will be reflected in the project evaluation calculus which determines the amount of investment in low-income housing. Given the present level of government subsidy necessary for low-income housing construction, the additional costs imposed by additional code enforcement will make the net benefits more negative and require additional subsidies

30. The initial figure comes from Professor Ackerman's "leverage" table which is reproduced at p. 1179 supra.

31. Regulating Slum Housing, supra note 2, at 1117. 
to maintain the same level of construction. If Professor Ackerman intends to increase the government subsidy for new low-income housing construction to offset this effect, he must include this additional subsidy in the costs of his plan. In either case, he can hardly dismiss the effect of increased costs on investment by reference to previous subsidies.

Concerning investment in housing in general and therefore the potential for trickle down, Professor Ackerman states:

Since the poor are dependent upon old buildings, the argument that code enforcement discourages new construction must be recast in a different, and far less imposing, form. One must argue that when a developer is considering the profitability of a middle-class residential apartment house, he will seriously take into account the possibility that in twenty or thirty years time the building's profitability might be significantly reduced if (a) it is then within a slum district and (b) the city is then actively pursuing a comprehensive code enforcement program. Even those who have the greatest faith in the entrepreneurial abilities of the American businessman would concede that the sensible developer would discount the possible costs of code enforcement twenty years hence as de minimis. Thus, if the government wishes to run a comprehensive code enforcement program without (a) increasing rent levels or (b) forcing Slumville families onto the streets or into permanently overcrowded conditions, it simply must make up the difference between the number of units withdrawn from the Slumville market and the number trickling down from Middleburg. It may properly ignore the alleged "long run" impact the program will have on housing supply. ${ }^{32}$

Once again the term de minimis is substituted for meaningful discussion. ${ }^{33}$ Present-value analysis which provides the comerstone of project evaluation does value a future dollar less than a present one. A dollar in twenty years is worth much less than one received today. But present-value analysis does not a priori negate the future amount. ${ }^{34}$

32. Id.

33. Professor Ackerman declares de minimis the possibility that professional investors would consider future costs in their present decisions to invest in new rental housing construction rather than alternative investment projects. The entire thrust of this argument is inconsistent with Professor Ackerman's alleged mode of analysis. Throughout his article Professor Ackerman employs a traditional economic analysis and defends this analysis against would-be critics as a useful means of analyzing slum housing. see, e.g., id. at 1141-48. His basic models assume that low-income tenants are sensitive to slight changes in rent and motivated to alter their behavior in reaction to these changes. Fet he contends that professional investors are a priori insensitive to alterations in the potential flow of income because those alterations will take place in twenty or thirty jears.

34. The difference in relative value of a dollar twenty years hence varies with the discount rate employed. At five percent, the present value of a dollar in twenty years is approximately thirty-eight cents; at six percent, it is worth approximatcly thirty-one cents; at seven percent, it is worth approximately twenty-six cents, etc. These figures are easily obtainable from any present-value table. 
A change of $\$ 50$ per month per unit in twenty or thirty years does not have zero present value. Such a change in flow would reduce the twentieth, twenty-first, etc. year's net benefits by $\$ 600$ per year. The actual present value of such a flow for the remaining twenty years of the structure ${ }^{35}$ at a discount rate of eight percent $^{30}$ would be approximately $\$ 1,250$. Is $\$ 1,250$ per rental unit de minimis?

Some perspective can be gained on this question by comparing this figure with the present value of a change in the mortgage rate. The supply of housing units is highly sensitive to changes in the borrowing (mortgage) rate. An increase of one-half of one percent can perceptibly diminish construction activity. If construction costs are assumed to be $\$ 20,000$ per rental unit $(\$ 1,000,000$ for a fifty unit apartment building), the mortgage is assumed to cover the forty year life of the building, and the eight percent discount rate is applied, the present value of the difference in costs produced by a one-half of one percent mortgage rate increase is approximately $\$ 995.37$ Why would investors be highly sensitive to $\$ 995$ while considering $\$ 1,250$ de minimis?

The figures can be changed by manipulating the discount rates, construction costs, mortgage duration or building life. ${ }^{38}$ The exact amounts are unimportant. Their general range is sufficient to indicate that the additional code costs imposed by Professor Ackerman's preferred program may have a strong detrimental effect upon the supply of housing to the poor. Professor Ackerman simply dismissed a question which should centrally concern any effort to assess the ef-

35. Forty years is generally assumed to be the cconomic life of a structure. In gell. cral, such a figure underestimates the actual physical life of most multiplc-unit structures. Thus, the use of forty years underestimates the period for which the code cost will be imposed, and therefore underestimates the present value of the code costs.

36. The eight percent rate represents the upper limit on mortgage rates and probably overestimates the alternative rate of return generally available. Again this overestimation of the discount rate underestimates the true present valuc of the code costs.

37. A .05 percent increase in the mortgage rate wolld mean an increase of $\$ 88.50$ per year in payments for a forty year mortgage with an initial principal of $\$ 20,000$. The present value of $\$ 88.50$ per year for forty years is $\$ 995.31$.

38. Professor Ackerman also alludes to the "uncertainty" of the imposition of code costs as minimizing their present impact on construction decisions, Such a point has theoretical validity. Indeed, if the probability is less than .8 and an expected value ap. proach is employed, the expected present value of code enforcement costs would be reduced below the level of the mortgage costs.

However, there is reason to believe that the probability of code enforcement is reasonably high given Professor Ackerman's plan.

New housing is important in Professor Ackerman's model because of the tricklc-down effect. The type of housing most important to trickle-down is that which has the po. tential of conversion to low-income housing. Eventually this housing must be available in sufficient supply or Professor Ackerman's trickle-down effect will be drastically reduced. It is exactly this sort of housing which will have the highest probability of facing increased costs due to code enforcement at some point in its useful life.

Professor Ackerman visualizes an effectual code enforcement program with broad scope and substantial impact. It is not a priori obvious that prospective investors will view the probability of future imposition of costs via such a program as insubstantial. Only carcful consideration of this effect will determine its substance. 
fects of quality improvement measures on the housing market. It may be desirable to sustain the long-term detrimental effects on investment to gain short-run advantages. But this issue is central, not tangential, and certainly not foreclosed.

\section{Effects on In-Migration}

Even if the supply of housing were fixed and insensitive to changes in cost conditions, the rent in Slumville would increase if the demand curve shifted to the right (if demand increased at all rental levels). An in-migration of tenants could occasion such a shift.

Professor Ackerman's preferred program would offer substantial quality improvements at no increase in rent. Such a program would seem likely to attract new tenants to the area. One likely source of inmigration is from nearby areas with housing quality only somewhat greater than the substandard quality available in the slum area prior to code enforcement. Another source of in-migration is from other cities or regions.

Professor Ackerman claims that neither of these sources will provide appreciable in-migration. In connection with in-migration from lower middle-class areas, he simply asserts that "it seems clear that the mere enforcement of housing code standards will not generate such a population movement to any significant extent." ${ }^{30}$ His only support for this assertion is a citation to a study which he describes as establishing the "virtual irreversibility" of a shift from white to non-white occupancy. Even if the study had as universal a scope as Professor Ackerman claims, such a citation hardly negates the possibility of in-migration from lower middle-class areas. The only reference is to race. Not all non-whites live in substandard housing. There is presumably a lower middle-class non-white population which could provide sufficient potential in-migration given quality improvements. Despite the connotation of terms such as "middle class" and "lower class," these categories represent rather arbitrary divisions along a continuum. A substantial improvement in slum housing quality should bring that housing to a quality level as great as or greater than the quality of the housing possessed by families somewhat further along the continuum. It does not seem "clear" that such improvement, very possibly accompanied by lower relative rent, will not attract substantial movement from lower middle-class areas.

In connection with inter-city or inter-regional migration, Professor Ackerman alludes to empirical studies which show that "the primary

39. Regulating Slum Housing, supra note 2, at 1140-41. 
magnet for migrants has been a strong job market." ${ }^{40}$ These studies may indicate that the attraction of substantially improved housing is weaker than the attraction of jobs, but it does not indicate that the former is an unimportant force. Professor Ackerman also alludes to the importance of the location of friends and family. It is difficult to assess a priori that such factors will dominate the effect of so unique an occurrence as a substantial improvement in living conditions at no increase in rent. The location of better employment and even the location of relatives need not exclude choice among qualities of housing. If families are strongly drawn by the greater family utility inherent in higher wages and better working conditions, it is difficult to exclude the possibility that greater family utility in the form of better housing conditions will not play a part.

Professor Ackerman's own calculus demands that low-income families gain at least moderately substantial utility from housing improvements. ${ }^{41}$ Surely Professor Ackerman should pause before dismissing the possibility that this utility is sufficient incentive for in-migration. While the incentive might operate only over a long time period, the correct approach is to determine the strength and timing of the incentive, not simply to deny its existence. ${ }^{42}$

\section{Projections}

The tone of the preceding discussion has been primarily negative. While it is tempting to suggest my own pet answer to the problems of housing and the poor, that would violate the basic counsel of the previous discussion. Professor Ackerman's difficulties did not stem from his inability to choose the "correct" program, but from his desire to promote a program before issues basic to the choice of any program had been stated, let alone solved.

40. Id. at 1143 .

41. Id. at $1126-27$.

42. Professor Ackerman's own discussion reflects the tension produced by his affinity for his assumptions. Thus, in support of the redistributive fairness of his plan, Professor Ackerman makes the following argument:

It follows a fortiori that code enforcement's relative equity is enhanced in a socicty like our own in which the general revenue fund is collected in significant part from taxes which are either regressive (like the sales tax) or haphazard and probably re. gressive (like the real estate tax), and in which owners of real estate receive substantial federal tax advantages.

Id. at 1176 (emphasis supplied and footnote omitted). He argues that the property tax can be regressive. But he fails to note that the property tax is regressive cxactly when landlords are able to pass the additional costs of the tax on to their lower-income lenants in the form of rent increases. If the landlords can pass this cost on to their tenants, they can pass on the costs of code improvements. If one is possible, both are possible. If pro. fessor Ackerman notes the regressive nature of the property tax in support of his arguments, he should also note the implications for the practical application of his inodal and for the program he proposes.

Professor Ackerman's second argument against the slumlord tax also cxhibits some of this internal tension. See p. 1183 supra. 
The rapid migration from rural to urban areas and between urban areas during the recent past may have produced a sizeable upward shift in the demand curve for urban rental units. The rate of this migration may have been underestimated by builders. This factor plus such market impediments as land use control legislation or code enforcement may have retarded the response of new construction to this shift in demand. These forces may have generated sufficient windfall profits or "economic rents" to provide a "landlords" fund" which could in theory be taxed away with little or no effect on the supply of housing. ${ }^{43}$ However, the existence and extent of these forces and their interaction with governmental programs aimed at promoting new housing construction are yet to be established.

Even if economic rents exist in a general geographic area, it will be difficult to identify the individual recipients of these rents and the extent of their receipts. Failure to identify the correct landlords or to assess the economic rents correctly would adversely affect the supply of housing. Information is not costless, and the identification and measurement could well prove too expensive relative to the revenues obtainable.

Even if the expected revenues outweigh these costs, it remains to consider how the economic rents will be acquired and redistributed. The realistic parameters of a substantial variety of in-kind and cashpayment programs will need consideration. The objects of the plans discussed, the breadth of the distribution, and the administrative costs of each program will require comparison. The "positive economics" of the administrative structures will also require careful consideration (e.g., how likely is it that a code enforcement bureau will be subverted into an agency which protects the interest of landlords against tenants or of wealthier landlords against poorer landlords?).

By its nature such a statement of issues is incomplete and shallow. When each issue is attacked intensively, it will generate many additional issues. The process of achieving the correct policy solution in this highly complex area is incremental at best. Small, frustratingly slow steps are the reality; sweeping pronouncements are illusion.

43. It is important here to distinguish between "quasi-rents," which would involve revenues in excess of variable costs in the short run, and "economic rents," which involve returns in excess of normal market return on investment. The former provided the basis for Professor Ackerman's model. Taxation of "quasi-rents" should affect the supply of housing. However, taxation of economic rents should not affect cren the long-run supply. That supply should expand with expanded demand since normal market rate would not be diminished by the taxation. It should be noted that this assertion is an uneasy one. Economic theory deals with equilibrium states. The dynamics of the process and rate of movement from one equilibrium to another is not as well handled by the theory. Thus, although the equilibrium supply of housing should cxpand to meet the new demand irrespective of the removal of economic rents, the rate at which the new equilibrium is attained could be affected adversely by the removal. 